\title{
Nutritional regulation of glucose-6-phosphatase gene expression in liver of the gilthead sea bream (Sparus aurata)
}

\author{
A. Caseras ${ }^{1}$, I. Metón ${ }^{1}$, C. Vives ${ }^{1}$, M. Egea ${ }^{1}$, F. Fernández ${ }^{2}$ and I. V. Baanante ${ }^{1 *}$ \\ ${ }^{1}$ Department de Bioquímica i Biologia Molecular, Facultat de Farmàcia, Universitat de Barcelona, Barcelona, Spain \\ ${ }^{2}$ Department d'Ecologia, Facultat de Biologia, Universitat de Barcelona, Barcelona, Spain
}

(Received 19 November 2001 - Revised 31 May 2002 - Accepted 2 July 2002)

\begin{abstract}
To examine the role of glucose-6-phosphatase (G6Pase) in glucose homeostasis in the diabeteslike experimental model of carnivorous fish, we analysed postprandial variations and the effect of starvation, ration size and diet composition on the regulation of G6Pase expression at the enzyme activity and mRNA level in the liver of gilthead sea bream (Sparus aurata). G6Pase expression increased in long-term starved or energy-restricted fish. In contrast to data reported for other fish species, short-term regulation of G6Pase expression was found in regularly fed $S$. aurata. G6Pase mRNA levels were lowest between 4 and $15 \mathrm{~h}$ after food intake, whereas minimal enzyme activity was observed $10-15 \mathrm{~h}$ postprandially. Alterations of plasma glucose levels affect G6Pase in mammals. However, the carbohydrate content of the diet did not affect hepatic expression of G6Pase in S. aurata, suggesting that a different molecular mechanism is involved in the control of G6Pase expression in fish. Although G6Pase was unaffected, highcarbohydrate low-protein diets increased glucokinase (GK) expression and thus allowed a metabolic adaptation favouring glycolysis over gluconeogenesis. Interestingly, only the nutritional conditions that promoted variations in the blood glucose levels resulted in changes in the hepatic expression of G6Pase. These findings indicate a concerted regulation of G6Pase and GK expression and suggest that the direction and rate of the glucose-glucose-6-phosphate substrate cycle flux is finely regulated in the liver of $S$. aurata, challenging the role attributed to deficient regulation of G6Pase or GK expression in the low ability of carnivorous fish to metabolize glucose.
\end{abstract}

Sparus aurata: Glucose-6-phosphatase: Glucokinase: Gene expression

Liver glucose-6-phosphatase (G6Pase: EC 3.1.3.9) contributes to blood glucose homeostasis by catalysing the dephosphorylation of glucose-6-phosphate to glucose, the terminal reaction of gluconeogenesis and glycogenolysis (Arion et al. 1975, 1980; Nordlie et al. 1999; van de Werve et al. 2000). The molecular events involved in the control of hepatic glucose production in non-model species, such as carnivorous fish, are poorly understood. In mammals, the hepatic expression of G6Pase is regulated by hormonal and nutritional status. Starvation and hormones that increase cAMP stimulate G6Pase expression, whereas re-feeding and insulin administration decrease G6Pase activity (Argaud et al. 1996; Minassian et al. 1999). Data in vivo and in vitro indicate that G6Pase expression in mammals is stimulated by glucose and xylitol irrespective of insulin through different signalling pathways (Massillon et al. 1996, 1998; Massillon, 2001).
The induction of G6Pase by glucose is paradoxical and has been linked to a balancing effect with that of insulin to avoid complete depletion of the enzyme during meal absorption, to control the hepatic glycogen storage and to prepare the transition to fasting periods (Massillon et al. 1996, 1998; Argaud et al. 1997; Chatelain et al. 1998; Massillon, 2001). Likewise, fructose-2,6-biphosphate, a strong inductor of glycolysis through allosteric activation of 6-phosphofructo-1-kinase and simultaneous inhibition of fructose-1,6-biphosphatase, stimulates G6Pase expression in the rat hepatoma-derived cells (Argaud et al. 1997). Although the molecular mechanism underlying transcriptional regulation of G6Pase expression remains largely unknown, recent advances indicate that the cAMP response element binding protein is involved in the activation of peroxisome proliferatoractivated receptor $\gamma$ co-activator-1, which in turn promotes

\footnotetext{
Abbreviations: BW, body weight; GK, glucokinase; G6Pase, glucose-6-phosphatase; HP, high-protein low-carbohydrate diet; LP, low-protein mediumcarbohydrate diet; LPHC, low-protein high-carbohydrate diet; MP, medium-protein low-carbohydrate diet.

* Corresponding author: Dr Isabel V. Baanante, fax +34 3 4021896, email baanante@farmacia.far.ub.es
} 
hepatic glucose output through stimulation of the expression of G6Pase and other gluconeogenic enzymes (Herzig et al. 2001; Yoon et al. 2001).

In carnivorous fish, glucose intolerance and limited use of dietary carbohydrates have been reported (Christiansen \& Klungsøyr, 1987; Cowey \& Walton, 1989; Wilson, 1994). In these animals hyperglycaemia lasts longer than in mammals both after glucose load and by feeding highcarbohydrate diets, a metabolic profile which mimics that caused by non-insulin-dependent diabetes mellitus in mammals (Palmer \& Ryman, 1972; Wright et al. 1998). It has been generally held that absence of hepatic glucokinase (GK: EC 2.7.1.1), the G6Pase counterpart in the glucose-glucose-6-phosphate substrate cycle, was one of the main causes of glucose intolerance in fish (Cowey \& Walton, 1989; Wilson, 1994). However, GK has recently been cloned from fish liver and its gene expression was found to be regulated by nutritional condition (Caseras et al. 2000; Panserat et al. 2000a,c 2001). Data on nutritional regulation of the hepatic expression of G6Pase in fish are scarce and contradictory. Long-term starvation increases G6Pase activity in rainbow trout (Salmo gairdneri; Morata et al. 1982), but decreases it in yellow perch (Perca flavescens; Foster \& Moon, 1991). In common carp (Cyprinus carpio), Shikata et al. (1993) found no effect of energy restriction on G6Pase activity. The effect of diet composition on G6Pase expression in fish is also species-specific. In the herbivorous fish Tilapia, Oreochromis niloticus, high-protein low-carbohydrate diets increased G6Pase activity (Shimeno et al. 1993). Recent reports have indicated no significant short- or long-term modulation of G6Pase expression in liver of rainbow trout irrespective of the carbohydrate content of the diet (Panserat et al. 2000b, 2001). These findings led Panserat et al. (2000b) to propose that deficient modulation through the glucose-glucose-6-phosphate flux in liver due to lack of regulation of G6Pase expression could explain the glucose intolerance reported for this species. In fact, overexpression of G6Pase leads to excessive hepatic glucose production in mammals, resulting in glucose intolerance and hyperglycaemia (O'Brien \& Granner, 1996; Seoane et al. 1997; Trinh et al. 1998). Since dysfunction of G6Pase gene expression may result in overproduction of glucose and a major cause of hyperglycaemia in carnivorous fish, the aim of the present study was to investigate the effect of various nutritional conditions on G6Pase expression in the liver of the gilthead sea bream (Sparus aurata).

\section{Materials and methods}

\section{Experimental animals}

Gilthead sea bream juveniles were obtained from Aquadelt S.A. (Sant Carles de la Ràpita, Tarragona, Spain) and maintained at $20^{\circ} \mathrm{C}$ in a $12 \mathrm{~h}$ light-dark cycle in 250 litre aquaria supplied with running seawater in a closed system with an active pump filter and u.v. lamps. To obtain liver samples, fish were anaesthetized with MS-222 (1:12500) and killed by cervical section at 9.00 hours, $24 \mathrm{~h}$ after the last meal, unless otherwise stated. Immediately, after dissection, blood samples were collected and the liver was freeze-clamped in liquid $\mathrm{N}_{2}$ and kept at $-80^{\circ} \mathrm{C}$ until use. The experimental procedures used in the present study met the guidelines of the Animal Use Committee of the University of Barcelona.

To study the regulation of the hepatic expression of G6Pase at mRNA and activity levels due to the nutritional status, fish were fed daily (9.00 hours) at $20 \mathrm{~g} / \mathrm{kg}$ body weight $(\mathrm{BW})$ for $18 \mathrm{~d}$. Following sampling, the rest of the animals were starved for $19 \mathrm{~d}$. The experimental diet contained: $17.1 \%$ carbohydrates, $47.6 \%$ protein, $12.5 \%$ lipids, $20.0 \%$ ash, $2.8 \%$ moisture and $19.2 \mathrm{~kJ}$ gross energy/g. The effect of energy restriction on G6Pase expression was examined by feeding daily three groups of fish on the same diet for $16 \mathrm{~d}$ at 10,20 or $40 \mathrm{~g} / \mathrm{kg} \mathrm{BW}$.

Short-term modulation of G6Pase expression was followed by monitoring the mRNA abundance and activity levels for $24 \mathrm{~h}$. To this end, fish were fed daily $(9.00$ hours) at $20 \mathrm{~g} / \mathrm{kg} \mathrm{BW}$ for $26 \mathrm{~d}$ on an experimental diet containing $13.1 \%$ carbohydrates, $47.7 \%$ protein, $16.2 \%$ lipids, $20.0 \%$ ash, $3 \%$ moisture and $20 \mathrm{~kJ}$ gross energy $/ \mathrm{g}$. Thereafter fish livers were dissected at time 0 ; the remaining fish immediately received the last meal and sampling was completed at different intervals within a $24 \mathrm{~h}$ period.

The effect of diet composition was studied using the diets shown in Table 1. The diets supplied to $S$. aurata, high-protein low-carbohydrate diet (HP), medium-protein low-carbohydrate diet (MP), low-protein mediumcarbohydrate diet (LP) and low-protein high-carbohydrate diet (LPHC), were selected to cover a composition range above and below the levels in commercially available diets for fish and contained increasing amounts of carbohydrate combined with three levels of protein. The proportions of gelatinized starch and fish-liver oil were

Table 1. Composition of the diets provided to Sparus aurata*

\begin{tabular}{lrrrr}
\hline Diet... & HP & MP & LP & LPHC \\
\hline Formulation (g/kg diet) & & & & \\
$\quad$ Fish meal & 91.40 & 81.74 & 64.35 & 64.35 \\
$\quad$ Fish oil† & 2.50 & 6.58 & 9.06 & 4.82 \\
$\quad$ Gelatinized maize starch & 3.60 & 9.18 & 24.09 & 28.33 \\
$\quad$ Vitamin mixture & 0.47 & 0.47 & 0.47 & 0.47 \\
$\quad$ Carrageenan & 2.00 & 2.00 & 2.00 & 2.00 \\
$\quad$ Butylated hydroxytoluene & 0.03 & 0.03 & 0.03 & 0.03 \\
Chemical analysis (\%) & & & & \\
$\quad$ Moisture & 2.6 & 3.0 & 3.1 & 3.4 \\
$\quad$ Protein & 58.5 & 47.7 & 37.9 & 37.4 \\
$\quad$ Fat & 8.7 & 16.2 & 16.9 & 11.6 \\
Carbohydrate§ & 9.9 & 13.1 & 26.0 & 31.6 \\
$\quad$ Ash & 20.3 & 20.0 & 16.1 & 16.0 \\
$\quad$ Gross energy (kJ/g) & 19.1 & 20.0 & 20.1 & 18.9 \\
\hline
\end{tabular}

HP, High-protein low-carbohydrate; MP, medium-protein low-carbohydrate; LP, low-protein medium carbohydrate; LPHC, low-protein high-carbohydrate. * Diets used in this work were manufactured by CPA (Barcelona, Spain).

†Fish oil with added all-trans retinol $(0.3 \mathrm{~g} / \mathrm{kg})$ and cholecalciferol $(2.5 \mathrm{mg} / \mathrm{kg})$.

‡Vitamin mixture provided (/kg diet): all-trans retinol, $11.28 \mathrm{mg}$; cholecalciferol, $117.5 \mathrm{mg}$; choline chloride, $1.88 \mathrm{~g}$; ascorbic acid, $1.18 \mathrm{~g}$; nicotinic acid, $160 \mathrm{mg}$; all-rac-tocopheryl acetate, $118 \mathrm{mg}$; thiamin- $\mathrm{HCl}, 118 \mathrm{mg}$; calcium pantothenate, $94 \mathrm{mg}$; riboflavin, $71 \mathrm{mg}$; pyridoxine- $\mathrm{HCl}, 24 \mathrm{mg}$; menadione- $\mathrm{HNaSO}_{3}, 19 \mathrm{mg}$; pteroylmonoglutamic acid, $14 \mathrm{mg}$; cyanocobalamin, $0.37 \mathrm{mg}$.

$\S$ Calculated by difference $(100-(\%$ protein + fat + ash + moisture $))$.

I Calculated from gross composition (protein, $24 \mathrm{~kJ} / \mathrm{g}$; lipid, $39 \mathrm{~kJ} / \mathrm{g}$; carbohydrate, $17 \mathrm{~kJ} / \mathrm{g}$ ). 
adjusted to achieve energy levels between 19 and $20 \mathrm{~kJ} / \mathrm{g}$. Fish were fed daily (9.00 hours) at $20 \mathrm{~g} / \mathrm{kg}$ BW for $18 \mathrm{~d}$. The diets were analysed by standard procedures (Windham, 1997).

\section{Enzyme activity assays and metabolite determinations}

G6Pase was assayed in microsomes isolated individually from $S$. aurata frozen liver previously homogenized in $50 \mathrm{mmol}$ imidazole/l, (pH 6.5), $250 \mathrm{mmol}$ sucrose $/ \mathrm{l}$, and $1 \mathrm{~g}$ Triton $\mathrm{X}-100 / 1$. The $100000 \mathrm{~g}$ microsomal fractions were re-suspended at a protein concentration of $10-20 \mathrm{~g} / 1$ in homogenization buffer and immediately used for G6Pase assays. The reaction mixture, with a final volume of $20 \mu \mathrm{l}$, contained $100 \mathrm{mmol}$ imidazole/l, (pH 6.5), 40 mmol glucose- 6 phosphate/l (to measure $\mathrm{V}_{\max }$ ) and $4 \mu \mathrm{l}$ of the microsomal suspension. Incubations, carried out for 0,8 and $15 \mathrm{~min}$ at $30^{\circ} \mathrm{C}$, were stopped by the addition of $80 \mu \mathrm{l}$ cold $100 \mathrm{~g}$ trichloroacetic acid/l, $20 \mathrm{~g}$ ascorbic acid/l. The production of glucose was determined using the GLUC GDH kit from Roche adapted for routine determinations in a COBAS MIRA S spectrophotometric analyser (Roche, Basel, Switzerland).

To measure GK activity, crude extracts were obtained by homogenization of the powdered frozen livers $(1: 5, \mathrm{w} / \mathrm{v})$ in $50 \mathrm{mmol}$ Tris- $\mathrm{HCl} / 1$ (pH 7.5), 4 mmol EDTA/l, $50 \mathrm{mmol}$ $\mathrm{NaF} / 1,100 \mathrm{mmol} \mathrm{KCl} / \mathrm{l}, 0.5 \mathrm{mmol}$ phenylmethylsulfonyl fluoride/1, $1 \mathrm{mmol}$ 1,4-dithiothreitol/1 and $250 \mathrm{mmol}$ sucrose $/ 1$ at $4{ }^{\circ} \mathrm{C}$. Crude extracts were filtered using Sephadex G-25 columns. GK enzyme activity was determined spectrophotometrically at $30^{\circ} \mathrm{C}$ by a previously described automated method (Caseras et al. 2000). GK activity was expressed as the rate of NADPH formation at $100 \mathrm{mmol}$ glucose $/ 1$, minus the corresponding rate at $0.5 \mathrm{mmol}$ glucose/l (hexokinase activity) after correction for glucose dehydrogenase activity, determined as GK activity in the presence of $2 \mathrm{mmol}$ NADP/1 and absence of both ATP and glucose-6-phosphate dehydrogenase (Borrebaek et al. 1993). A stoichiometric ratio of 2 mol NADPH formed per mol of phosphorylated glucose was considered.

Protein content in the microsomal suspensions and hepatic extracts was determined at $30^{\circ} \mathrm{C}$ in the COBAS MIRA S analyser at $600 \mathrm{~nm}$ by the Bradford method (Bradford, 1976), using bovine serum albumin as a standard.

The serum glucose was determined using the GLUC GDH kit (Roche) adapted to the COBAS MIRA S analyser.

\section{RNA isolation and Northern blotting analysis}

Total RNA was obtained from frozen tissue by ultracentrifugation in guanidine thiocyanate through a caesium chloride cushion, following standard procedures (Sambrook et al. 1989). In Northern blotting experiments, total RNA $(20 \mu \mathrm{g})$ was loaded onto each lane of agarose gel $(10 \mathrm{~g} / \mathrm{l})$ containing $0.67 \mathrm{~mol}$ formaldehyde/l. Electrophoresis was performed for $4 \mathrm{~h}$ at $50 \mathrm{~V}$. Thereafter, RNA were transferred overnight onto NY13 nytran membranes (Schleicher \& Schuell, Dassel, Germany) in $5 \times$ SSC $(1 \times$ standard saline citrate $(\mathrm{SSC})=150 \mathrm{mmol} \mathrm{NaCl} / \mathrm{l}, 15 \mathrm{mmol}$ sodium citrate/l, pH 7.5). RNA was crosslinked to the membranes by u.v. irradiation for $3 \mathrm{~min}$. To analyse the expression of
G6Pase in the liver of $S$. aurata, the membranes were hybridized with a homologous probe obtained by polymerase chain reaction with the forward primer F1 (5'-GTCCTGGGAGACTGGCTCAAC- $3^{\prime}$ ) and the reverse primer F2R $\left(5^{\prime}\right.$-CCACTTCTGGGCTTTCTCCA- $\left.3^{\prime}\right)$, which correspond to nucleotides 223-243 and 759-740, respectively, in the cDNA sequence that we previously cloned (GenBank accession number AF151718). After prehybridizations were carried out for $5 \mathrm{~h}$ at $42^{\circ} \mathrm{C}$ in $1 \mathrm{~mol} \mathrm{NaCl} / 1,50 \mathrm{mmol}$ $\mathrm{Na}_{2} \mathrm{HPO}_{4} / \mathrm{l}(\mathrm{pH} 6.5), 7.5 \times$ Denhardt's, $12.6 \mathrm{~mol}$ formamide/l, $0.2 \mathrm{mmol}$ dextran sulfate $/ \mathrm{l}, 10 \mathrm{~g}$ sodium dodecyl sulfate $/ 1,0.5 \mathrm{~g}$ DNA from herring sperm $/ 1$, the radiolabelled probe was added and hybridizations proceeded overnight at $42^{\circ} \mathrm{C}$. Membranes were washed three times for $15 \mathrm{~min}$ at $42^{\circ} \mathrm{C}$ with $2 \times \mathrm{SSC}, 2 \mathrm{~g}$ sodium dodecyl sulfate $/ \mathrm{l}$, once for $20 \mathrm{~min}$ with $0.1 \times \mathrm{SSC}, 2 \mathrm{~g}$ sodium dodecyl sulfate/l at $65^{\circ} \mathrm{C}$ and finally once for $20 \mathrm{~min}$ with $0 \cdot 1 \times \mathrm{SSC}, 2 \mathrm{~g}$ sodium dodecyl sulfate $/ 1$ at $68^{\circ} \mathrm{C}$. GK expression was analysed by Northern blot with a GK homologous probe reported elsewhere (Caseras et al. 2000). The membranes were retested with $\beta$-actin for normalization. Membranes were exposed to Hyperfilm-MP (Amersham, Bucks, UK) at $-80^{\circ} \mathrm{C}$. Autoradiographed films were quantitatively analysed by scanning densitometry.

\section{Statistics}

Data were analysed with the SuperANOVA program (Abacus Concepts, Berkeley, CA). Differences between experimental conditions were determined according to Duncan's multiple range test with significant levels at $P<0.05, P<0.01$ and $P<0.001$, which are indicated by distinct letters or by asterisks.

\section{Results}

\section{Effect of starvation and energy restriction}

The influence of nutritional status on the hepatic expression of G6Pase from $S$. aurata was addressed through a fed-starved experimental design both at mRNA and enzyme activity levels. Northern blotting analysis using a homologous probe showed that the G6Pase mRNA abundance in liver of $19 \mathrm{~d}$ starved fish was 2-fold higher than in fed animals (Fig. 1). The G6Pase activity in starved animals presented a moderate increase of about $30 \%$ (Fig. 1(B)). The serum glucose levels depended on the nutritional status. Glycaemia in 19 d starved fish ( $n$ 5) was 590 (SD 80) mg glucose/l, whereas in fed fish ( $n$ 5) was 890 (SD 130) mg glucose/l.

To study the effect of energy restriction on the expression of G6Pase in the liver of $S$. aurata, the mRNA abundance and the enzyme activity were determined in three groups of fish fed daily at $10 \mathrm{~g} / \mathrm{kg} \mathrm{BW}$, $20 \mathrm{~g} / \mathrm{kg} \mathrm{BW}$ and $40 \mathrm{~g} / \mathrm{kg} \mathrm{BW}$ for $16 \mathrm{~d}$. The G6Pase mRNA levels varied according to the amount of diet supplied to $S$. aurata. Feeding at $10 \mathrm{~g} / \mathrm{kg} \mathrm{BW}$ resulted in G6Pase mRNA levels 1.5- and 2.4-fold greater, significantly higher than those observed in fish fed at $20 \mathrm{~g} / \mathrm{kg}$ and $40 \mathrm{~g} / \mathrm{kg} \mathrm{BW}$, respectively (Fig. 2). Consistently, the G6Pase activity was significantly higher in the fish fed 
(A)

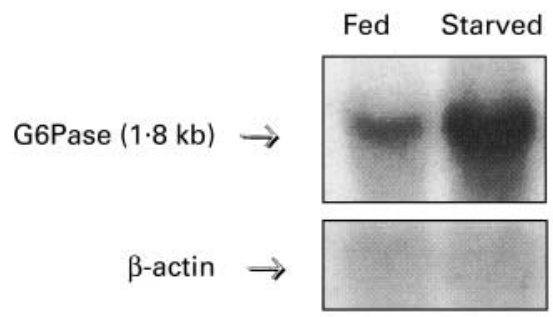

(B)

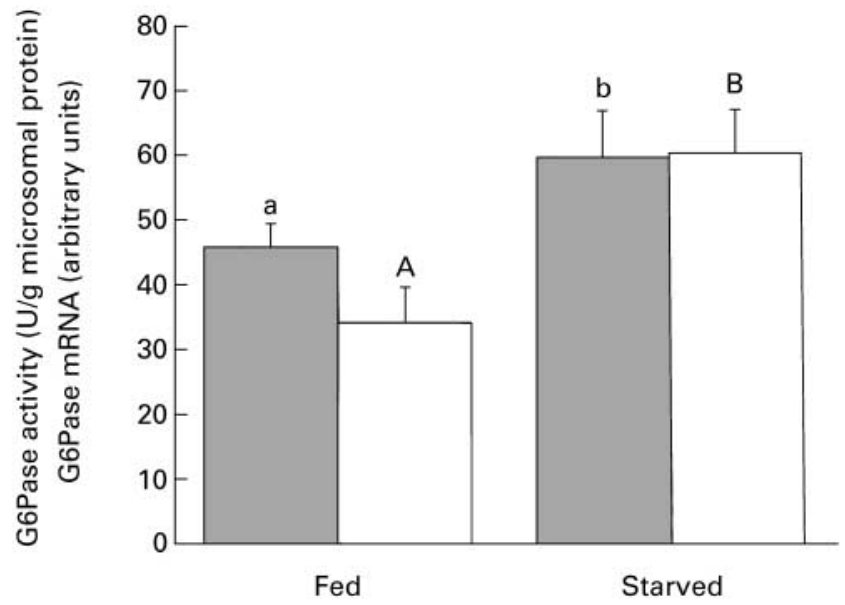

Fig. 1. Effect of starvation on the hepatic expression of glucose-6phosphatase (G6Pase) in Sparus aurata. (A), Representative Northern blot of G6Pase mRNA levels in liver of fish fed daily at $20 \mathrm{~g} / \mathrm{kg}$ body weight for $18 \mathrm{~d}$ (fed) and $19 \mathrm{~d}$ starved fish (starved). Total hepatic RNA $(20 \mu \mathrm{g})$ was loaded in each lane. (B), G6Pase enzyme activity $((\square)$ and densitometric analysis of G6Pase mRNA $(\square)$ determined in liver of fed and $19 \mathrm{~d}$ starved fish. Mean values are shown, with their standard deviations represented by vertical bars, for four fish per group. Different letters (lower case for G6Pase activity and upper case for G6Pase mRNA) denote significant differences $(P<0.01)$.

the lowest ration size of $10 \mathrm{~g} / \mathrm{kg} \mathrm{BW}$. Thus, feeding at $10 \mathrm{~g} / \mathrm{kg} \mathrm{BW}$ resulted in a similar effect on G6Pase expression to starvation. Likewise, we previously found that feeding ration sizes below $10 \mathrm{~g} / \mathrm{kg} \mathrm{BW}$ or starvation similarly affect the activity of other key enzymes involved in intermediary metabolism (Metón et al. 1999b). However, no difference was found between the activity values determined in the fish fed at $20 \mathrm{~g} / \mathrm{kg} \mathrm{BW}$ or $40 \mathrm{~g} / \mathrm{kg} \mathrm{BW}$ (Fig. 2(B)). Similarly, we previously observed that other key enzyme activities involved in hepatic intermediary metabolism, such as 6-phosphofructo-1-kinase, pyruvate kinase, 6-phosphogluconate dehydrogenase or alanine aminotransferase, showed a tendency to plateau at a ration size of $20 \mathrm{~g} / \mathrm{kg} \mathrm{BW}$ (Metón et al. 1999b).

The serum glucose levels also depended on the ration size, with values of 830 (SD 10) $\mathrm{mg}$ glucose/l for the fish
(A)

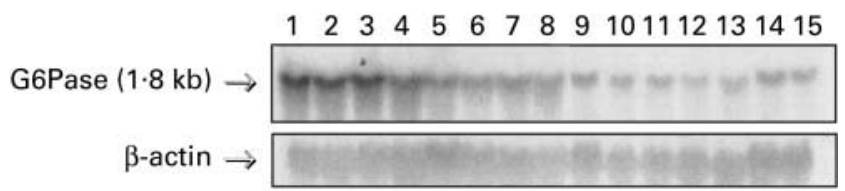

(B)

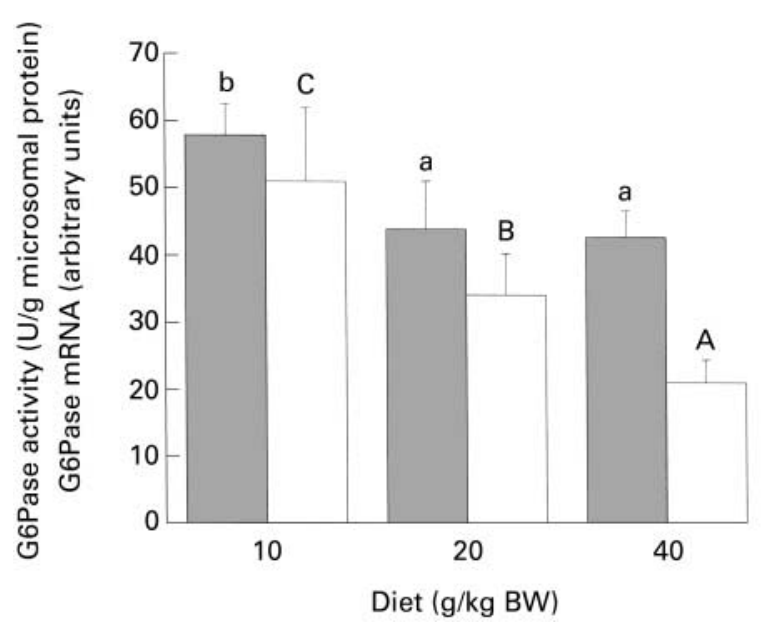

Fig. 2. Effect of energy restriction on the hepatic glucose-6phosphatase (G6Pase) expression in Sparus aurata. (A), Representative Northern blot of G6Pase mRNA levels in liver of fish fed daily at $10 \mathrm{~g} / \mathrm{kg}$ body weight (BW) (lanes $1-4), 20 \mathrm{~g} / \mathrm{kg}$ BW (lanes $5-8$ ) and $40 \mathrm{~g} / \mathrm{kg}$ BW (lanes 9-15) for $16 \mathrm{~d}$. Total hepatic RNA $(20 \mu \mathrm{g})$ was loaded in each lane. (B), G6Pase activity ( $\square)$ and densitometric analysis of mRNA levels $(\square)$ determined in liver of fish fed for $16 \mathrm{~d}$ at $10 \mathrm{~g} / \mathrm{kg} \mathrm{BW}, 20 \mathrm{~g} / \mathrm{kg} \mathrm{BW}$ and $40 \mathrm{~g} / \mathrm{kg} \mathrm{BW}$ per d. Mean values are shown, with their standard deviations represented by vertical bars, for at least four fish per group. Different letters (lower case for G6Pase activity and upper case for G6Pase mRNA) denote significant differences between rations $(P<0.05)$.

fed at $10 \mathrm{~g} / \mathrm{kg} \mathrm{BW}(n$ 4), 1000 (SD 100) mg glucose/l for those fed at $20 \mathrm{~g} / \mathrm{kg} \mathrm{BW}(n$ 4) and 1130 (SD 130) $\mathrm{mg}$ glucose/l for those fed at $40 \mathrm{~g} / \mathrm{kg} \mathrm{BW}(n 4)$.

\section{Postprandial variations of glucose-6-phosphatase expression}

To unravel the control of liver glucose production during postprandial periods in carnivorous fish, we further studied the short-term modulation of G6Pase expression. Thus, the postprandial variations of hepatic G6Pase expression were followed for $24 \mathrm{~h}$ in the liver of regularly fed fish. At postprandial time $4-15 \mathrm{~h}$, the G6Pase mRNA levels were 3 -fold lower than at preprandial time 0 (Fig. 3). A delayed decrease in G6Pase activity with minimal values $10-15 \mathrm{~h}$ after food intake was observed in liver of regularly fed S. aurata (Fig. 3(B)).

The serum glucose levels also showed postprandial variations. At time 0 (preprandial), glycaemia was 760 
(A)

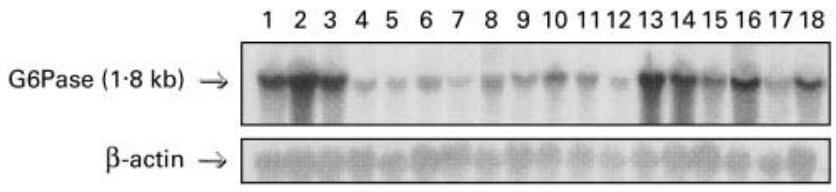

(B)

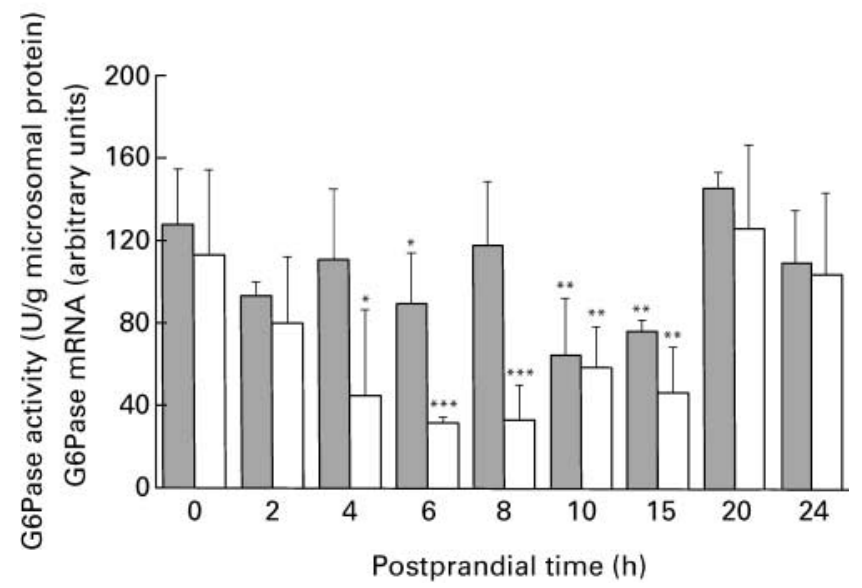

Fig. 3. Postprandial variations of glucose-6-phosphatase (G6Pase) expression in liver of Sparus aurata. (A), Representative Northern blot of G6Pase mRNA levels at preprandial time 0 (lanes 1-3) and postprandial times $6 \mathrm{~h}$ (lanes $4-6$ ), 8h (lanes 7-9), 10 h (lanes 10-12), $20 \mathrm{~h}$ (lanes 13-15) and $24 \mathrm{~h}$ (lanes 16-18). Total fish hepatic RNA $(20 \mu \mathrm{g})$ was loaded in each lane. (B), G6Pase activity $(\square)$ and densitometric analysis of fish liver G6Pase mRNA levels $(\square)$ at time 0 (preprandial) and postprandial times 2, 4, 6, 8, 10, 15, 20 and $24 \mathrm{~h}$. Mean values are shown, with their standard deviations represented by vertical bars, for three-six fish per group. Mean values were significantly different to those at time 0 : ${ }^{*} P<0.05$, ${ }^{\star \star} P<0.01,{ }^{\star * \star} P<0.001$.

(sD 200) mg glucose/l ( $n$ 4). Following the intake of food, the serum glucose rapidly increased to reach the higher levels at postprandial time $4 \mathrm{~h} ; 1620$ (SD 90) $\mathrm{mg}$ glucose/l ( $n$ 4). Thereafter, glycaemia decreased and gradually returned to preprandial values. The serum glucose observed at postprandial times $6 \mathrm{~h}$ and $10 \mathrm{~h}$ was 980 (SD 40) $\mathrm{mg}$ glucose/l ( $n$ 4) and 660 (SD 220) mg glucose/l ( $n$ 4), respectively.

\section{Effect of diet composition}

Since long-term (starvation and energy restriction) and short-term (regularly fed animals) modulation of G6Pase expression occurred in the liver of $S$. aurata, we further studied the long-term effect of feeding on various diets differing in nutrient composition. To assess whether the G6Pase gene expression in liver of $S$. aurata was affected by diet composition, four groups of animals were given various diets differing in the nutrient formulation but with a similar energetic level (Table 1). As shown in Fig. 4, the dietary composition failed to significantly modify the hepatic mRNA content or the G6Pase activity.
(A)

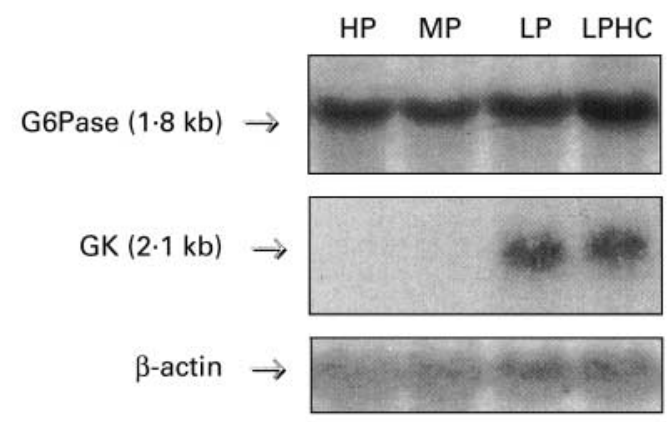

(B)

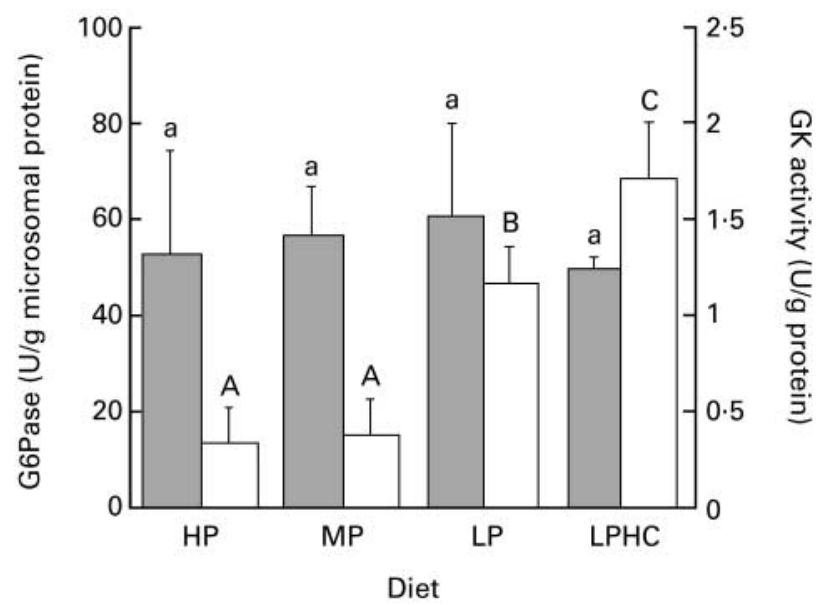

Fig. 4. Effect of diet composition on the hepatic expression of glucose-6-phosphatase (G6Pase) and glucokinase (GK) in Sparus aurata. (A), Representative Northern blotting analyses of G6Pase and GK mRNA levels in liver of fish fed daily at $20 \mathrm{~g} / \mathrm{kg}$ body weight (BW) diets high-protein low-carbohydrate (HP), medium-protein low-carbohydrate (MP), low-protein medium carbohydrate (LP) or low-protein high-carbohydrate (LPHC) for $18 \mathrm{~d}$. Total hepatic RNA $(20 \mu \mathrm{g})$ was loaded in each lane. (B), G6Pase ( $\square$ ) and GK ( $\square$ ) enzyme activities determined in liver of fish fed daily the four different diets at $20 \mathrm{~g} / \mathrm{kg} \mathrm{BW}$ for $18 \mathrm{~d}$. Mean values are shown, with the standard deviations represented by vertical bars, for at least four fish per group. Different letters (lower case for G6Pase activity and upper case for GK activity) denote significant differences $(P<0.01)$. For details of diets, see p. 608.

Although the supply of high-carbohydrate diets may result in a greater availability of sugars, the serum glucose levels did not show significant differences among the fish fed the different diets, with values of 790 (SD 80) mg glucose/l (for the fish fed diet HP ( $n$ 4), 770 (SD 230) mg glucose/l for those fed diet MP ( $n$ 4), 880 (SD 220) mg glucose/l for those fed diet LP ( $n$ 4) and 700 (SD 180) $\mathrm{mg}$ glucose/l for those fed diet LPHC $(n 4)$. Since glucose homeostasis in the liver is maintained through the concerted action of both G6Pase and GK, we also analysed the effect of diet composition on the expression of GK, both at mRNA and activity levels. Northern blot experiments indicated that the supply of medium- or highcarbohydrate low-protein diets (diets LP and LPHC) 
resulted in a huge accumulation of hepatic GK mRNA, while hardly detectable levels were observed in the fish fed low-carbohydrate diets (diets HP and MP) (Fig. 4(A)). Consistently, the GK activity measured in the fish fed diets LP and LPHC were significantly higher, 3-fold and 4-fold, respectively, than in those fed diets HP and MP (Fig. 4(B)).

\section{Discussion}

G6Pase is a key enzyme in gluconeogenesis and glucose output from the liver (Nordlie et al. 1999; van de Werve et al. 2000). In the present study, the hepatic expression of G6Pase in $S$. aurata depended on nutritional status. Long-term starvation and energy restriction resulted in stimulation of G6Pase expression at both mRNA and enzyme activity levels. Consistently, starvation and energy restriction decrease the expression of GK, the glycogen content and the activity of other key enzymes involved in glycolysis and the pentose phosphate pathway in this species (Bonamusa et al. 1992; Metón et al. 1999a,b, 2000; Caseras et al. 2000). The stimulation of G6Pase expression observed in starved and energyrestricted $S$. aurata, together with the reported inhibition of the hepatic expression of GK (Caseras et al. 2000), point to hepatic glucose export through predominance of glucose-6-phosphate hydrolysis over glucose phosphorylation in such conditions. In contrast to previous reports indicating lack of regulation of G6Pase expression in the liver of rainbow trout after food intake (Panserat et al. $2000 b$, 2001), we observed a postprandial short-term modulation of G6Pase mRNA and enzyme activity in the liver of regularly fed $S$. aurata. Minimal mRNA levels were detected at postprandial time $4-15 \mathrm{~h}$, whereas the lower G6Pase activity was found $10-15 \mathrm{~h}$ after food intake. Our findings are consistent with the large dependence upon G6Pase expression of hepatic glucose cycling in the postprandial state in mammals (Minassian et al. 1999; Nordlie et al. 1999). Besides, the higher blood glucose levels in $S$. aurata were observed $4 \mathrm{~h}$ after feeding; thereafter glycaemia decreased to preprandial values. Furthermore, postprandial variations of GK expression also occur in the liver of regularly fed fish, reaching a peak at postprandial time 6-8h (Caseras et al. 2000). Thus, the rise in glycaemia was followed by a decrease in G6Pase expression, which, together with the reported GK stimulation, leads to the metabolization of glucose in the liver. Therefore, our results suggest a concerted postprandial short-term regulation of G6Pase and GK expression in liver of regularly fed $S$. aurata. In rats, the suppression of hepatic glucose production by hyperinsulinaemia and hyperglycaemia involves the inhibition of G6Pase activity (Guignot \& Mithieux, 1999). A similar situation may well occur in $S$. aurata following the intake of food. In fasted rats, inhibition of G6Pase activity appears to play an important role in the repletion of liver glycogen during re-feeding, with a significant decrease at postprandial time $3 \mathrm{~h}$ (Minassian et al. 1999). Our results indicate a delayed inhibitory effect on G6Pase expression that may be related to the fact that fish have developed a long-term starvation response. At short term, changes in glycogen in fish are limited and thus there would not be an urgent need to restore its levels (Baanante et al. 1991).

Feeding $S$. aurata on diets differing in composition, but with similar energy levels, had no long-term effect on the hepatic G6Pase expression or blood glucose levels. Since the flux of the glucose-glucose-6-phospate substrate cycle in liver depends on the counteracting effects of G6Pase and GK, we also determined the effect of diet composition on GK. Interestingly, the diets similar to the natural diet of carnivorous fish, i.e. with low carbohydrate content (diets HP and MP), resulted in extremely low hepatic GK mRNA and activity levels. These results suggest that gluconeogenesis predominates over glycolysis in the liver of $S$. aurata fed low-carbohydrate diets and are consistent with de novo synthesis of glucose and glycogen from non-carbohydrate compounds, such as lactate, amino acids and glycerol, which is considered an important pathway in carnivorous fish (Cowey \& Walton, 1989; Baanante et al. 1991; Metón et al. 1999b). On the other hand, medium- or highcarbohydrate low-protein diets (diets LP and LPHC) markedly increased hepatic GK expression, but did not affect that of G6Pase, enhancing the rate of hepatic glucose phosphorylation. Likewise, we previously reported that high-carbohydrate low-protein diets stimulate 6-phosphofructo-2-kinase activity in the liver of $S$. aurata, resulting in enhanced fructose-2,6-bisphosphate levels and thus leading to increased 6-phosphofructo-1-kinase:fructose1,6-bisphosphatase and pyruvate kinase:fructose-1,6bisphosphatase activity ratios (Metón et al. 1999b, 2000). Thus, partial substitution of protein by carbohydrates in the diet results in an increased GK:G6Pase in the liver and reveals the ability of $S$. aurata to utilize dietary carbohydrates through increased hepatic glucose uptake. In contrast to previous studies on mammals (Massillon et al. 1996, 1998; Argaud et al. 1997; Chatelain et al. 1998; Massillon, 2001), increased glucose metabolism did not modulate the G6Pase expression in the liver of $S$. aurata. In this fish species, while high-carbohydrate low-protein diets increase the hepatic fructose-2,6-bisphosphate content (Metón et al. 1999b, 2000), the liver G6Pase mRNA was not affected. Thus, a distinct mechanism is involved in the control of G6Pase expression in $S$. aurata by dietary nutrients. The fact that in the conditions studied, variations in the hepatic G6Pase expression were always in the opposite direction to changes in glycaemia suggests a relationship between blood glucose levels and G6Pase expression in the liver of this species. Further studies will be required to characterize the molecular link between nutrients, hormonal status, and transcriptional and posttranscriptional mechanisms involved in G6Pase gene expression.

In conclusion, the present study shows that regulation of G6Pase gene expression in the diabetes-like experimental model of carnivorous fish differs from mammals. Specifically, the hepatic expression of G6Pase in S. aurata in the conditions studied was finely modulated and suggests a concerted regulation in the expression of the enzymes that control the glucose-glucose-6-phosphate substrate cycle flux in the liver. These findings demonstrate that glucose intolerance in a carnivorous fish such as $S$. aurata 
cannot be attributed to lack of regulation of G6Pase gene expression.

\section{Acknowledgements}

This study was supported by grants from MEC (Spain), DGICYT PB96-1488 and MCYT (Spain), BMC20000761. C. V. is in receipt of a fellowship from the Generalitat de Catalunya. We thank the Language Advisory Service of the University of Barcelona for correcting the English manuscript.

\section{References}

Argaud D, Kirby TL, Newgard CB \& Lange AJ (1997) Stimulation of glucose-6-phosphatase gene expression by glucose and fructose-2,6-bisphosphate. Journal of Biological Chemistry 272, 12854-12861.

Argaud D, Zhang Q, Pan W, Maitra S, Pilkis SJ \& Lange AJ (1996) Regulation of rat liver glucose-6-phosphatase gene expression in different nutritional and hormonal states. Gene structure and 5'-flanking sequence. Diabetes 45, 1563-1571.

Arion WJ, Lange AJ, Walls HE \& Ballas LM (1980) Evidence for the participation of independent translocation for phosphate and glucose 6-phosphate in the microsomal glucose-6-phosphatase system. Interactions of the system with orthophosphate inorganic phosphate and carbamyl phosphate. Journal of Biological Chemistry 255, 10396-10406.

Arion WJ, Wallin BK, Lange AJ \& Ballas LM (1975) On the involvement of a glucose 6-phosphate transport system in the function of microsomal glucose-6-phosphatase. Molecular and Cellular Biochemistry 6, 75-83.

Baanante IV, García de Frutos P, Bonamusa L \& Fernández F (1991) Regulation of fish glycolysis-gluconeogenesis, role of fructose 2,6- $\mathrm{P}_{2}$ and PFK-2. Comparative Biochemistry and Physiology 100B, 11-17.

Bonamusa L, García de Frutos P, Fernández F \& Baanante IV (1992) Nutritional effects on key glycolytic-gluconeogenic enzyme activities and metabolite levels in the liver of the teleost fish Sparus aurata. Molecular Marine Biology and Biotechnology 1, 113-125.

Borrebaek B, Waagbo R, Christophersen B, Tranulis MA \& Hemre G-I (1993) Adaptable hexokinase with low affinity for glucose in the liver of Atlantic salmon (Salmo salar). Comparative Biochemistry and Physiology 106B, 833-836.

Bradford MM (1976) A rapid and sensitive method for the quantitation of microgram quantities of protein utilizing the principle of protein-dye binding. Analytical Biochemistry 72, 248-254.

Caseras A, Metón I, Fernández F \& Baanante IV (2000) Glucokinase gene expression is nutritionally regulated in the liver of gilthead seabream (Sparus aurata). Biochimica et Biophysica Acta 1493, 135-141.

Chatelain F, Pegorier JP, Minassian C, Bruni N, Tarpin S, Girard J \& Mithieux G (1998) Development and regulation of glucose6-phosphatase gene expression in rat liver intestine and kidney, in vivo and in vitro studies in cultured fetal hepatocytes. Diabetes 47, 882-889.

Christiansen DG \& Klungsøyr L (1987) Metabolic utilization of nutrients and the effects of insulin in fish. Comparative Biochemistry and Physiology 88B, 701-711.

Cowey CB \& Walton MJ (1989) Intermediary metabolism. In Fish Nutrition, pp. 260-321 [JE Halver, editor]. San Diego: Academic Press.

Foster GD \& Moon TW (1991) Hypometabolism with fasting in the yellow perch (Perca flavescens), a study of enzymes, hepatocyte metabolism and tissue size. Physiological Zoology 64, 259-275.

Guignot L \& Mithieux G (1999) Mechanisms by which insulin associated or not with glucose may inhibit hepatic glucose production in the rat. American Journal of Physiology 277, E984-E989.

Herzig S, Long F, Jhala US, Hedrick S, Quinn R, Bauer A, Rudolph D, Schutz G, Yoon C, Puigserver P, Spiegelman B \& Montminy M (2001) CREB regulates hepatic gluconeogenesis through the coactivator PGC-1. Nature 413 , $179-183$.

Massillon D (2001) Regulation of glucose-6-phosphatase gene by glucose occurs by transcriptional and post-transcriptional mechanisms. Journal of Biological Chemistry 276, 4055-4062.

Massillon D, Barzilai N, Chen W, Hu M \& Rossetti L (1996) Glucose regulates in vivo glucose-6-phosphatase gene expression in the liver of diabetic rats. Journal of Biological Chemistry 271, 9871-9874.

Massillon D, Chen W, Barzilai N, Prus-Wertheimer D, Hawkins M, Liu R, Taub R \& Rossetti L (1998) Carbon flux via the pentose phosphate pathway regulates the hepatic expression of the glucose-6-phosphatase and phosphoenolpyruvate carboxykinase genes in conscious rats. Journal of Biological Chemistry 273, 228-234.

Metón I, Caseras A, Fernández F \& Baanante IV (2000) 6-Phosphofructo-2-kinase/fructose-2,6-bisphosphatase gene expression is regulated by diet composition and ration size in liver of gilthead sea bream Sparus aurata. Biochimica et Biophysica Acta 1491, 220-228.

Metón I, Caseras A, Mediavilla D, Fernández F \& Baanante IV (1999a) Molecular cloning of a cDNA encoding 6-phosphofructo-2-kinase/fructose-2,6-bisphosphatase from liver of Sparus aurata, nutritional regulation of enzyme expression. Biochimica et Biophysica Acta 1444, 153-165.

Metón I, Mediavilla D, Caseras A, Cantó E, Fernández F \& Baanante IV (1999b) Effect of diet composition and ration size on key enzyme activities of glycolysis-gluconeogenesis pentose phosphate pathway and amino acid metabolism in liver of gilthead sea bream (Sparus aurata). British Journal of Nutrition 82, 223-232.

Minassian C, Montano S \& Mithieux G (1999) Regulatory role of glucose-6-phosphatase in the repletion of liver glycogen during refeeding in fasted rats. Biochimica et Biophysica Acta 1452, $172-178$.

Morata P, Vargas AM, Sanchez-Medina F, Garcia M, Cardenete G \& Zamora S (1982) Evolution of gluconeogenic enzyme activities during starvation in liver and kidney of the rainbow trout (Salmo gairdneri). Comparative Biochemistry and Physiology 71B, 65-70.

Nordlie RC, Foster JD \& Lange AJ (1999) Regulation of glucose production by the liver. Annual Review of Nutrition 19, 379-406.

O'Brien RM \& Granner DK (1996) Regulation of gene expression by insulin. Physiological Reviews 76, 1109-1161.

Palmer TN \& Ryman BE (1972) Studies on oral glucose tolerance tests in fish. Journal of Fish Biology 4, 311-319.

Panserat S, Blin C, Médale F, Plagnes-Juan E, Brèque J, Krishnamoorthy J \& Kaushik S (2000a) Molecular cloning tissue distribution and sequence analysis of complete glucokinase cDNAs from gilthead seabream (Sparus aurata), rainbow trout (Oncorynchus mykiss) and common carp (Cyprinus carpio). Biochimica et Biophysica Acta 1474, 61-69.

Panserat S, Capilla E, Gutierrez J, Frappart PO, Vachot C, Plagnes-Juan E, Aguirre P, Brèque J \& Kaushik S (2001) Glucokinase is highly induced and glucose-6-phosphatase poorly repressed in liver of rainbow trout (Oncorhynchus 
mykiss) by a single meal with glucose. Comparative Biochemistry and Physiology 128B, 275-283.

Panserat $\mathrm{S}$, Médale $\mathrm{F}$, Blin $\mathrm{C}$, Brèque $\mathrm{J}$, Vachot $\mathrm{C}$, Plagnes-Juan E, Gomes E, Krishnamoorthy R \& Kaushik S (2000b) Hepatic glucokinase is induced by dietary carbohydrates in rainbow trout, gilthead seabream and common carp. American Journal of Physiology 278, R1164-R1170.

Panserat S, Médale F, Brèque J, Plagnes-Juan E \& Kaushik S (2000c) Lack of significant long-term effect of dietary carbohydrates on hepatic glucose-6-phosphatase expression in rainbow trout (Oncorhynchus mykiss). Journal of Nutritional Biochemistry 11, 22-29.

Sambrook J, Fritsch EF \& Maniatis T (1989) Extraction, purification and analysis of messenger RNA from eukaryotic cells. In Molecular Cloning, a Laboratory Manual, 2nd ed., pp. 7.1-7.87 [C Nolan, editor]. Cold Spring Harbour: Cold Spring Harbour Laboratory Press.

Seoane J, Trinh K, O’Doherty RM, Gómez-Foix AM, Lange AJ, Newgard CB \& Guinovart JJ (1997) Metabolic impact of adenovirus-mediated overexpression of the glucose-6-phosphatase catalytic subunit in hepatocytes. Journal of Biological Chemistry 272, 26972-26977.

Shikata T, Kheyyali D \& Shimeno S (1993) Effect of feeding rates on hepatopancreatic enzymes and body composition in common carp. Nippon Suisan Gakkaishi 59, $835-839$.
Shimeno S, Ming D-C \& Takeda M (1993) Metabolic response to dietary carbohydrate to lipid ratios in Oreochromis niloticus. Nippon Suisan Gakkaishi 59, 827-833.

Trinh KY, O'Doherty RM, Anderson P, Lange AJ \& Newgard CB (1998) Perturbation of fuel homeostasis caused by overexpression of the glucose-6-phosphatase catalytic subunit in liver of normal rats. Journal of Biological Chemistry 273, $31615-31620$.

van de Werve G, Lange AJ, Newgard C, Méchin M-C, Li Y \& Berteloot A (2000) New lessons in the regulation of glucose metabolism taught by the glucose-6-phosphatase system. European Journal of Biochemistry 267, 1533-1549.

Wilson RP (1994) Utilization of dietary carbohydrate by fish. Aquaculture 124, 67-80.

Windham WR (1997) Animal feed. In Official Methods of Analysis, 16th ed., pp. 4.1-4.46 [P Cunnif, editor]. Gaithersburg, MD: AOAC International.

Wright JR Jr, O'Hali W, Yang H, Han X-X \& Bonen A (1998) GLUT-4 deficiency and severe peripheral resistance to insulin in the teleost fish tilapia. General Comparative Endocrinology 111, 20-27.

Yoon JC, Puigserver P, Chen G, Donovan J, Wu Z, Rhee J, Adelmant G, Stafford J, Kahn CR, Granner DK, Newgard CB \& Spiegelman BM (2001) Control of hepatic gluconeogenesis through the transcriptional coactivator PGC-1. Nature 413, $131-138$. 